\title{
Occurrence and management of invasive alien species in Hungarian protected areas compared to Europe
}

\author{
Ágnes Csiszár ${ }^{1 *}$, Pál Kézdy², Márton Korda ${ }^{1}$, Dénes Bartha ${ }^{1}$ \\ ${ }^{1}$ Department of Botany and Nature Conservation, Faculty of Forestry, University of Sopron, \\ Bajcsy-Zsilinszky 4, 9400 Sopron, Hungary \\ ${ }^{2}$ Duna-Ipoly National Park Directorate, Költő 21, 1121 Budapest, Hungary
}

\begin{abstract}
CsiszÁr, Á., KÉzDY, P., KordA, M., BARTHA, D., 2020. Occurrence and management of invasive alien species in Hungarian protected areas compared to Europe. Folia Oecologica, 47 (2): 178-191.

A questionnaire survey was carried out to examine the problems caused by invasive alien species (IAS) in Hungarian protected areas (PAs). Results from 144 PAs were evaluated and compared with a previous study of 21 European countries. In the European survey, the most important threats were habitat loss and fragmentation, Hungarian respondents put IAS in first place. Eradication, control and prevention were mentioned among the best strategies against invasive species in both surveys, but Hungarian PA managers emphasized the efficiency of habitat restoration and regulatory as well. Comparing the harmful animals and plants occurring in most Hungarian and European PAs, we found nearly 30\% similarity. In most Hungarian PAs domestic cat (Felis catus Linnaeus, 1758) and black locust (Robinia pseudoacacia L.) were indicated as most harmful species. The results of our study draw the attention to the species, which are highly invasive in Hungary, but are missing from the European PAs list, therefore may pose a potential threat to other protected areas of Europe.
\end{abstract}

Keywords

European legalisation, invasive alien species, invasion list, protected areas, web survey

\section{Introduction}

The rapid spread of invasive alien species (IAS) is one of the most significant problems in protected areas (PAs) worldwide, which is indicated by FoxCROFT et al. (2017), reviewing 1,857 publications about invasive alien species in PAs. The percentage of alien species in PAs varies between 5-30\% globally (UsHeR, 1988), while in European PAs within the range of 6-18\% (PYŠEK et al., 2013); however, data comparability is restricted due to differences in invasive species definition. Several lists of invasive alien plant and animal species have been prepared together with their impacts, differing in the given area and viewpoint. One of the first lists was compiled by UsHER (1988), who collected data from 24 nature reserves all over the world. Concerning Europe, the DAISIE project compiled a list of IAS which contains 10,771 taxa and created a list of the most dangerous 100 species (Roy et al., 2019). The European and Mediterranean Plant Protection Organization (EPPO) published five different lists of alien plant species according to their management activities (EPPO, 2020). The list of European Alien Species Information Network (EASIN, 2020) serves information about 5,032 alien animal and 6,421 alien plant species. NeNTwig et al. (2018) proposed a list of the worst alien species for Europe containing 54 plants, 49 invertebrates, 40 vertebrates and 6 fungi species based on the generic impact scoring system (GISS). De PoORTER (2007) examined the impacts and

*Corresponding author: e-mail: csiszar.agnes@uni-sopron.hu 
management of IAS in PAs at both a global and regional level. Her list contains 58 animal and plant species which have significant impact on European PAs; including 37 plants: 25 trees and shrubs, eight herbaceous, perennial and four annual species. As some authors (PYŠEK et al., 2008, 2013; Hulme et al., 2013; FoxCROFT et al., 2014) have highlighted, the invasion processes in European PAs are scantly studied, and there is no comprehensive list of alien plants for PAs. Detailed and comprehensive studies on invasive plants in PAs have been published in Czech Republic, Slovenia, and the Mediterranean islands (PYŠEK et al., 2002; VeEnVliet and Humar, 2011; Brundu, 2014). GALLARDO et al. (2017) investigated the current and future potential distributions of 100 most invasive species in Europe and found that the predicted richness of invaders is significantly lower inside the PAs than outside. A new viewpoint appeared in the study of GENOVESI and MONACO (2014): the authors surveyed how impacts of IAS were rated by the managers of protected areas (PAs) in Europe. Altogether 138 responses from 21 European countries were taken from a web survey, ranging from alpine to marine PAs. One of the results of this study was list of the most invasive animals and plants as indicated by European PA managers. Hungarian PAs were not included in the survey.

Invasive alien species can cause severe problems in Hungarian agriculture, forestry, and human health (TöRöK et al., 2003). 5.5\% of the natural and semi-natural habitats of Hungary is covered by perennial alien species; the floodplain shrub- and woodlands and open grasslands are especially threatened by invasive plants (BотTA-DuKÁT, 2008). Beside the natural habitats, presence of IAS in agricultural lands is also considerable, e.g. common ragweed (Ambrosia artemisiifolia L.) occurs on 5.4 million ha of arable land (KAZINCZI et al., 2008). Several publications reported on invasive plant species and invaded habitats (BAlogh et al., 2008; Botta-Dukát, 2008; Botta-DukáT and BALOGH, 2008; KirÁLY et al., 2008; CSECSERITS et al., 2016), but only a few are focusing the practice of IAS control (CsISZÁr and KoRdA, 2017). Concerning invasive alien animals in Hungary, studies are not well-balanced according to taxonomic respects, the most extensively studied groups are invasive arthropods (RIPKA, 2010; CsóKA et al., 2012) and water invaders (BoRZA et al., 2011; BóDIs et al., 2012; TAKÁcs et al., 2017). The Council of Biological Invasion Experts established by the Ministry of Rural Development compiled a scientific list of IAS (MAGYAR ÁLLAMI TERMÉSZETVÉDELEM, 2020).

Since the lists of invasive alien species need to be regularly updated and no list of IAS endangering Hungarian protected areas has been prepared, we would like to answer the question which alien plants and animals cause currently problems or potentially spread in our protected areas. Our results were compared with European IAS lists and surveys in order to explore the factors that promote and hinder the control of invasive species in the Hungarian protected areas. The comparison can help identify gaps and draw attention to species whose distribution is predictable in the future, thus helping to develop a more effective prevention or control strategy.

\section{Materials and methods}

Having examined the threat and problems caused by IAS in Hungarian PAs, we carried out a net survey, with the aim to compare it with a European level survey (GENOVESI and Monaco, 2014), via a questionnaire of the same content and using the same program (SurveyMonkey). The questionnaire was sent to colleagues in all national park directorates responsible for management of different PAs (national parks, landscape protection sites, nature reserves, Natura 2000 sites, etc.), and were completed by them between October and December, 2016 (Appendix). The questionnaire contained twelve questions, ten of which related to IAS in protected areas, and two to general information of PAs (name, location) or optional comments about the survey. Questions belonged to the following question types: simple textbox (e.g. "Please indicate the top invasive (most harmful) animal species in your protected area? (Please tick at least 1 up to 5 responses"), multiple choice (e.g. "Is there a checklist of alien animals present in your protected area?"), and matrix/rating scale (e.g. "What in your opinion are the worst impacts caused by invasive species in your protected area? (Please tick at least 1 response, rank 1 is the worst)". In case of the rating scale questions (rating from 1 to 5), a cumulative rank score was applied. It means that rank 1 was multiplied by 5 , rank 2 multiplied by 4 , etc. for each answer option and these multiples were summed finally. All answers concerning every type of PAs were accepted, but overlapping areas were excluded from the evaluation choosing one of them after individual consideration. Answers about unidentified areas were also excluded from the evaluation. After this screening, altogether 144 answers from 73 respondents remained since one respondent may be responsible for more than one protected area. The survey is a good representation of Hungarian PAs, since answers from national park directorates concern sites from plain, hilly and mountain regions. During the interpretation of the European and Hungarian surveys, the results were illustrated in the same scale because of the approximately equal number of answers (138 and 144). During the comparison of lists of the most harmful animal and plant species of European and Hungarian surveys, Jaccard similarity coefficient was calculated.

\section{Results and discussion}

Hereinafter, we discuss the evaluation and conclusions concerning the different questions comparing the Hungarian PAs and European PAs (Genovesi and Monaco, 2014). Evaluating the European results, the most important threats are habitat loss and fragmentation, while the Hungarian respondents put IAS in first place since $97 \%$ of PAs are threatened by invasive species to some measure (Fig. 1). In addition, a considerable number of answers mentioned the unfavourable effects of overexploitation (e.g. intensive agriculture, forest- or game management), succession, and spread of native species. Among the other factors the lack of grassland or water management, and global aridification caused by climate change were mentioned. 




Fig. 1. The most important threats in the Hungarian and European PAs. Answers to the question "What in your opinion are the most important threats to your protected area?" (cumulative rank score).

The checklists of invasive animals and plants of both European and Hungarian PAs were incomplete. In Hungary, this lack is more significant; $80 \%$ of PAs have not got any assessment at all, and only the $15 \%$ of PAs have partial checklist concerning invasive animals. In case of the invasive plants, the situation is more favourable: $85 \%$ of the areas have some sort of assessment. This difference can be explained by the limited detectability of the animals due to their non-stationary characteristics, occasionally size and need of a specialist within in zoology. Management measures implemented on invasive alien animals showed a similar deficiency as the checklists, which results partly from the latter: in almost one third of the Hungarian PAs (29\%) no management actions were implemented (Fig. 2a).

The status of invasive plant management is much more favourable; only approx. 5-6\% of PAs are without any control activities (Fig. 2b). In European PAs, the most outstanding activities are monitoring and surveillance (24\%), followed by control activity (15\%). In contrast, both monitoring (16\%) and control (17\%) reached a similar rate in Hungary, which shows that these activities were carried on simultaneously, mostly supported by EU projects.

Regarding the worst impacts of biological invasion, the habitat transformation and competition with native species were regarded as the most considerable impacts in both surveys (Fig. 3). In contrary to European survey,
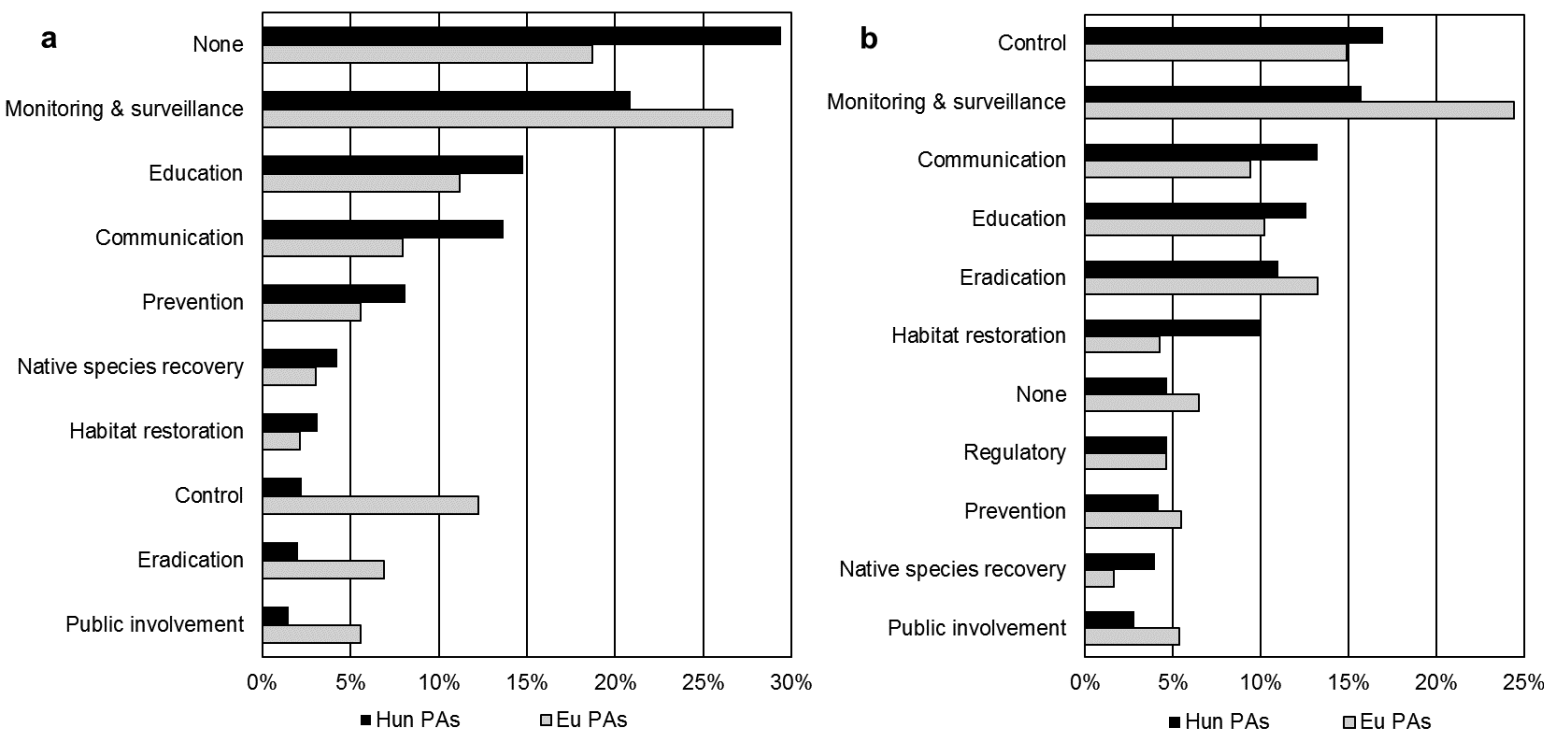

Fig. 2. The most important management activities implemented against invasive alien a) animals and b) plants in the Hungarian and European PAs. Answers to the question "What are the kind of management activities of the top invasive a) animals and b) plants being implemented in your protected area?" 
Hungarian respondents indicated the damaging landscape, agriculture and forestry much more significant than European PA managers. The reason behind it could be the high amount of considerably transformed floodplain forests and riverine ecosystems by invasive tree species. Damage in agriculture and human health were also better emphasized

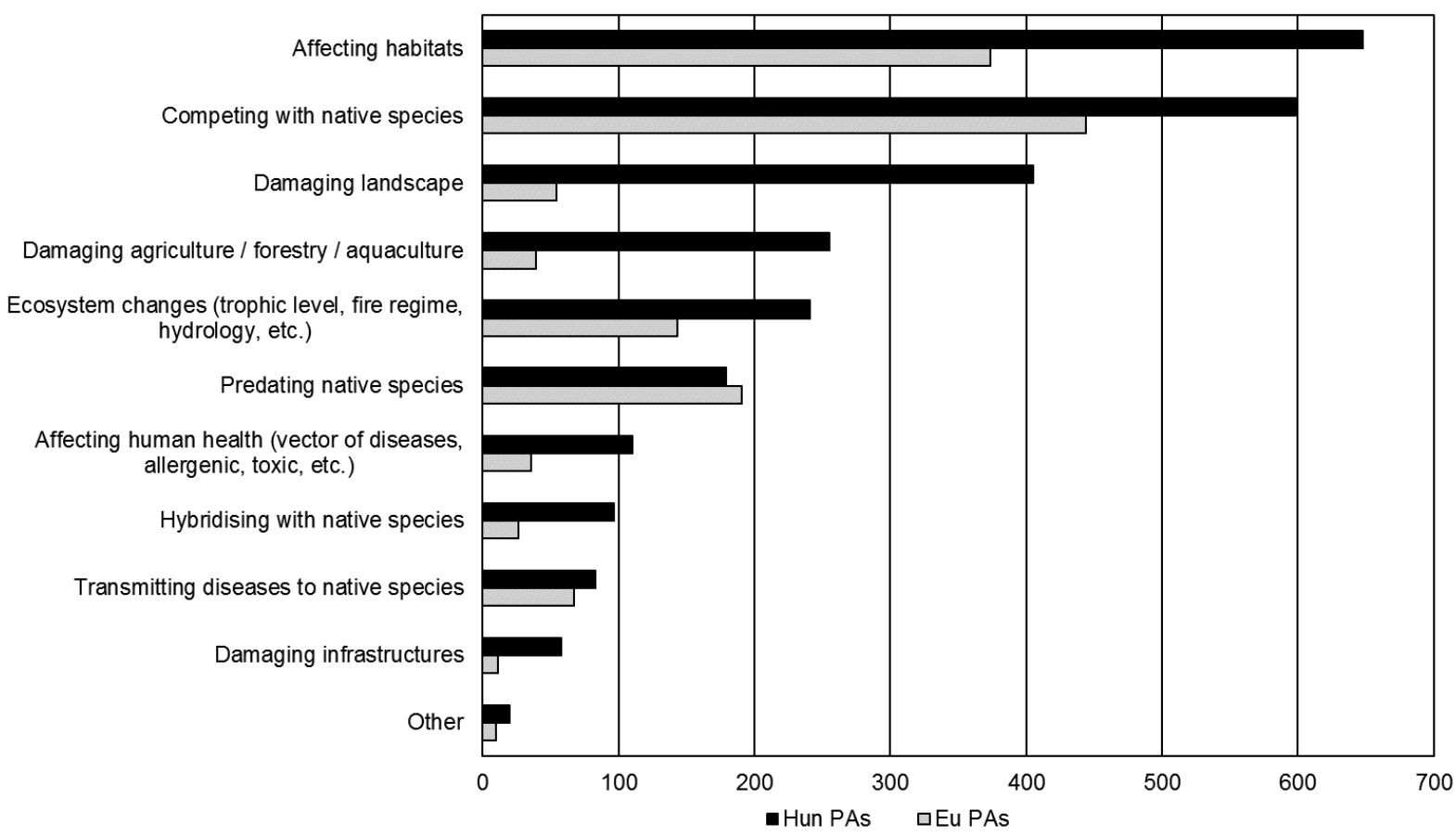

Fig. 3. Worst impacts caused by IAS to the Hungarian and European PAs. Answers to the question "What in your opinion are the worst impacts caused by invasive species in your protected area?" (cumulative rank score).



Fig. 4. Most effective management options to deal with IAS in the Hungarian and European PAs. Answers to the question "What in your opinion are the most effective management options to deal with the spread of invasive species in your protected area?" (cumulative rank score). 


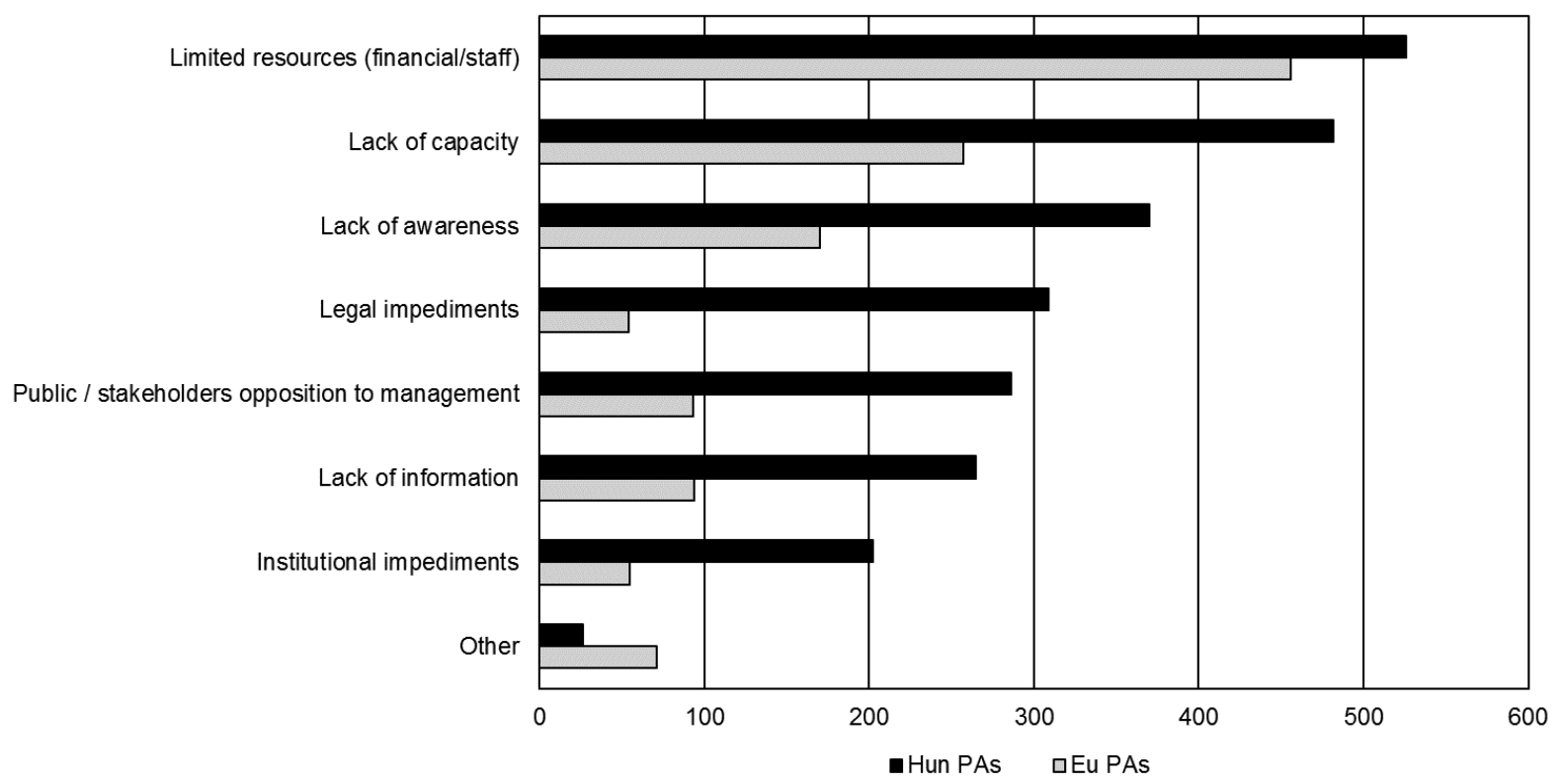

Fig. 5. Key factors inhibiting effective struggle against the spread of IAS in the Hungarian and European PAs. Answers to the question "What in your opinion are the key impediments in dealing with the spread of invasive species in your protected area?" (cumulative rank score).

by Hungarian PA managers, this can be explained by the high dominance of common ragweed (Ambrosia artemisiifolia) in Hungarian agricultural lands. The presence of this species as a harmful species in 19 Hungarian PAs is an interesting result, since its occurrence in natural habitats is disputed.

There were differences in the most effective management options; European PA managers considered eradication, control, and prevention as the best strategies, while Hungarian respondents in addition regarded habitat restoration and regulatory as the best methods. (Fig. 4). The most important key factors inhibiting the struggle against the spread of IAS were evaluated similarly: lack of resources (financial/staff), capacity, and awareness were the leading factors (Fig. 5).

In case of both animals and plants, respondents could select the five most harmful alien species per PA. Hungarian PA managers selected 30 animal species in total, which were compared with other European lists of IAS (Table 1). Eleven species of the 30 compiled by Hungarian respondents are included in the DAISIE top 100 list (Roy et al., 2019) and in the EU Regulation list too (EUROPEAN COMMISSION, 2020), 17 species correspond with the European list published by GeNOVESI and Monaco (2014), and 14 species are present in the list of the worst alien species for Europe (NENTwig et al., 2018). Only two species are not represented in the list of European Alien Species Information Network (EASIN, 2020), 24 species are rated high-, and 4 species low/unknown impact. Hungarian PA managers considered the domestic cat the most dangerous species in more than half of the PAs because of predatory activity. Invasive role of domestic cat has been widely proved not only in islands but throughout in Europe via its various ecological impact including predation, competition, hybridization, and disease transmission (O'BRIEN et al, 2009; Medina et al., 2013). The harlequin ladybird (Harmonia axyridis Pallas, 1773) reached 51\% among the top invasive species, and this is the only adventive Coleopteran species which was introduced intentionally. The impact of the harlequin ladybird is not only displacing native species, but causing biodiversity loss by transforming the composition of a whole insect community (Roy et al., 2012). There are five fish species among the top invasive species. It is also meaningful that 19 of the 30 most harmful animal species are water invaders. It confirms KELLER et al. (2011) findings that European aquatic ecosystems contain the highest numbers of alien species because of high disturbance, human access and connectivity to other ecosystems. Among the mammals, mouflon (Ovis aries musimon Pallas, 1762) and fallow deer (Dama dama Linnaeus, 1758) can cause serious problems in Hungarian PAs, both were introduced for hunting purpose. Our results corresponded with the study of CARPIO et al. (2016), which demonstrated the significant role of hunting in biological invasion as a pathway of IAS. The Jaccard index shows approx. 35\% similarity $\left(\mathrm{S}_{\mathrm{J}}=0.3469\right)$ between the most harmful animals of European and Hungarian PAs. The differences can be explained partly by the indigenousness of species, e.g. Sus scrofa (Linnaeus, 1758), Cyprinus carpio (Linnaeus, 1758), and Sander lucioperca (Linnaeus, 1758) are native in Hungary but alien in some part of Europe. Furthermore, the marine ecosystems are missing from Hungary so the habitats of marine species are not given. In the case of some species like Sciurus carolinensis (Gmelin, 1788) the climatic conditions and habitats are suitable, but the species has not reached the country yet.

Hungarian PA managers selected 35 most harmful plant species in total, which were compared with other European lists inter alia the EU list of IAS (Table 2). Among Hungarian harmful species, 8 occur in the DAISIE top 100 
Table 1. List of the most harmful animals compiled by the Hungarian PA managers comparing with European lists

\begin{tabular}{|c|c|c|c|c|c|c|}
\hline Species & $\begin{array}{l}\text { Hungarian } \\
\text { PAs }(144)^{1}\end{array}$ & $\begin{array}{c}\text { European } \\
\text { PAs }(138)^{2}\end{array}$ & $\begin{array}{c}\text { EU } \\
\text { Regula- } \\
\text { tion }^{3}\end{array}$ & EASIN $^{4}$ & $\begin{array}{l}\text { DAISIE } \\
\text { Top } 100^{5}\end{array}$ & $\begin{array}{c}\text { Europe's } \\
\text { worst } \\
100^{6} \\
\end{array}$ \\
\hline Felis catus & 74 & 4 & & High & & \\
\hline Harmonia axyridis & 73 & 6 & & High & $x$ & $x$ \\
\hline Carassius gibelio & 53 & 5 & & High & & $x$ \\
\hline Ovis aries musimon & 27 & 3 & & High & & $x$ \\
\hline Ameiurus nebulosus & 27 & & & High & & \\
\hline Dama dama & 22 & 3 & & $\begin{array}{l}\text { Low/ } \\
\text { Unkn }\end{array}$ & & \\
\hline Pseudorasbora parva & 20 & 2 & $x$ & High & $x$ & $x$ \\
\hline Arion vulgaris & 17 & 5 & & High & $x$ & \\
\hline Lepomis gibbosus & 17 & 6 & $x$ & High & & \\
\hline Perccottus glenii & 14 & & $x$ & High & & \\
\hline Orconectes limosus & 10 & 10 & $x$ & High & & $x$ \\
\hline Sinanodonta woodiana & 8 & & & High & & \\
\hline Trachemys scripta & 7 & 11 & $x$ & High & $x$ & \\
\hline Metcalfa pruinosa & 4 & & & High & & \\
\hline Pacifastacus leniusculus & 4 & 9 & $x$ & High & & $x$ \\
\hline Ameiurus melas & 3 & 4 & & $\begin{array}{l}\text { Low/ } \\
\text { Unkn }\end{array}$ & & \\
\hline Leptoglossus occidentalis & 2 & 2 & & $\begin{array}{l}\text { Low/ } \\
\text { Unkn }\end{array}$ & & \\
\hline Myocastor coypus & 2 & 18 & $x$ & High & $x$ & $x$ \\
\hline Procambarus fallax f. virginalis & 2 & & $\times$ & High & & $x$ \\
\hline Anguilla anguilla & 1 & & & & & \\
\hline Canis lupus familiaris & 1 & & & & & \\
\hline Corbicula spp. & 1 & & & High & $x$ & $x$ \\
\hline Dreissena spp. & 1 & & & High & $x$ & $x$ \\
\hline Hypophthalmichthys molitrix $\times$ H. nobilis & 1 & & & High & & \\
\hline Neogobius melanostomus & 1 & & & High & $x$ & \\
\hline Nyctereutes procyonoides & 1 & 9 & $x$ & High & $x$ & $x$ \\
\hline Ondatra zibethicus & 1 & 7 & $x$ & High & $x$ & $x$ \\
\hline Ponticola kessleri & 1 & & & $\begin{array}{l}\text { Low/ } \\
\text { Unkn }\end{array}$ & & \\
\hline Potamopyrgus antipodarum & 1 & & & High & & $x$ \\
\hline Procyon lotor & 1 & 3 & $x$ & High & $x$ & $x$ \\
\hline
\end{tabular}

${ }_{1,2}$ Number of PAs in brackets; ${ }^{2}$ GeNOVESI and MonACO, 2014; ${ }^{3}$ List of invasive alien species of Union concern (Commission Implementing Regulation (EU) 2016, 2017, 2019); ${ }^{4}$ EASIN, 2020; ${ }^{5}$ DAISIE (Roy et al., 2019); ${ }^{6}$ List of the worst alien species for Europe (NeNTwig et al., 2018).

list (Roy et al., 2019), 13 in the EPPO list (EPPO, 2020), and 18 in the European PAs list (Genovesi and Monaco, 2014). Only 5 species are present in EU Regulation list (European Commission, 2020), while 9 occur in the list of the worst alien species for Europe (NENTwIG et al., 2018). Only two species are not represented in the list of EASIN (2020), 22 species are rated high-, and 11 species low/ unknown impact. Among the plant species, the most outstanding is black locust (Robinia pseudoacacia L.), which was marked as a harmful species in $66 \%$ of the PAs. Its spread is facilitated by the considerable cultivation area: black locust plantations cover $24 \%$ of the Hungarian forest stands (BARTHA et al., 2008). Robinia pseudoacacia was the second most important neophyte in the Czech PAs as well (PYšEK et al., 2012, 2013), and its further invasion was also predicted into nature reserves and endangered habitats promoted by climate change (KLEINBAUER et al., 2010). All of the top ten species were introduced more than 100 years ago, mostly intentionally. Therefore, their invasion success could be explained not only by effective spreading 
Table 2. List of the most harmful plants compiled by the Hungarian PA managers comparing with European lists

\begin{tabular}{|c|c|c|c|c|c|c|c|}
\hline Species & $\begin{array}{l}\text { Hungarian } \\
\text { PAs }(144)^{1}\end{array}$ & $\begin{array}{c}\text { European } \\
\text { PAs }(138)^{2}\end{array}$ & $\begin{array}{c}\text { EU } \\
\text { Regulation }^{3}\end{array}$ & EASIN $^{4}$ & $\begin{array}{l}\text { DAISIE } \\
\text { Top } 100^{5}\end{array}$ & $\mathrm{EPPO}^{6}$ & $\begin{array}{c}\text { Europe's } \\
\text { worst } \\
100^{7} \\
\end{array}$ \\
\hline Robinia pseudoacacia & 95 & 26 & & High & $x$ & & $x$ \\
\hline Asclepias syriaca & 73 & 3 & $\times$ & High & & & \\
\hline Ailanthus altissima & 64 & 16 & $\times$ & High & $\times$ & Inv & \\
\hline Elaeagnus angustifolia & 58 & & & High & & & $x$ \\
\hline Solidago gigantea & 46 & 8 & & High & & Inv & \\
\hline Amorpha fruticosa & 40 & 6 & & High & & Inv & \\
\hline Acer negundo & 38 & 6 & & High & & & \\
\hline Solidago canadensis & 32 & 9 & & High & & Inv & $x$ \\
\hline Fraxinus pennsylvanica & 24 & & & $\begin{array}{l}\text { Low/ } \\
\text { Unkn }\end{array}$ & & & \\
\hline Celtis occidentalis & 21 & & & $\begin{array}{l}\text { Low/ } \\
\text { Unkn }\end{array}$ & & & \\
\hline Ambrosia artemisiifolia & 19 & 10 & & High & $\times$ & Inv & $x$ \\
\hline Fallopia spp. & 18 & 48 & & High & $\times$ & Inv & $\times$ \\
\hline Echinocystis lobata & 14 & 4 & & High & $\times$ & & \\
\hline Symphyotrichum spp. & 10 & 2 & & High & & & \\
\hline Prunus serotina & 9 & 5 & & High & $\times$ & Inv & $\times$ \\
\hline Impatiens parviflora & 8 & 5 & & High & & Pot & \\
\hline Vitis vulpina & 7 & & & $\begin{array}{l}\text { Low/ } \\
\text { Unkn }\end{array}$ & & & \\
\hline Impatiens glandulifera & 6 & 29 & $\times$ & High & $\times$ & Inv & \\
\hline Syringa vulgaris & 4 & & & $\begin{array}{l}\text { Low/ } \\
\text { Unkn }\end{array}$ & & & \\
\hline Tamarix tetrandra & 4 & & & & & & \\
\hline Erigeron canadensis & 3 & & & High & & & \\
\hline Heracleum mantegazzianum & 3 & 11 & $\times$ & High & $\times$ & Inv & $\times$ \\
\hline Parthenocissus inserta & 2 & & & & & & \\
\hline Phytolacca americana & 2 & 4 & & $\begin{array}{l}\text { Low/ } \\
\text { Unkn }\end{array}$ & & & \\
\hline Elymus elongatus & 1 & & & $\begin{array}{l}\text { Low/ } \\
\text { Unkn }\end{array}$ & & & \\
\hline Forsythia $\times$ intermedia & 1 & & & $\begin{array}{l}\text { Low/ } \\
\text { Unkn }\end{array}$ & & & \\
\hline Helianthus tuberosus & 1 & 2 & & High & & Inv & \\
\hline Laburnum anagyroides & 1 & & & $\begin{array}{l}\text { Low/ } \\
\text { Unkn }\end{array}$ & & & \\
\hline Lycium barbarum & 1 & & & $\begin{array}{l}\text { Low/ } \\
\text { Unkn }\end{array}$ & & & \\
\hline Mahonia aquifolium & 1 & & & High & & & \\
\hline Pinus nigra & 1 & & & $\begin{array}{l}\text { Low/ } \\
\text { Unkn }\end{array}$ & & & \\
\hline Sorghum halepense & 1 & & & High & & & \\
\hline Xanthium spinosum & 1 & & & $\begin{array}{l}\text { Low/ } \\
\text { Unkn }\end{array}$ & & & \\
\hline Azolla filiculoides & 1 & 6 & & High & & Obs & $\times$ \\
\hline Hydrocotyle ranunculoides & 1 & & $\times$ & High & & Reg & $\times$ \\
\hline
\end{tabular}

\footnotetext{
${ }^{1,2}$ Number of PAs in brackets; ${ }^{2}$ GenOVESI and Monaco, 2014; ${ }^{3}$ List of invasive alien species of Union concern (Commission Implementing Regulation (EU) 2016, 2017, 2019); ${ }^{4}$ EASIN, 2020; ${ }^{5}$ DAISIE (Roy et al., 2019); ${ }^{6}$ EPPO, 2020; Reg, recommended for regulation as quarantine pests; Inv, invasive alien plants; Obs, observation list of invasive alien plants; Pot, other documented potentially invasive plants; ${ }^{7}$ List of the worst alien species for Europe (NENTwIG et al., 2018).
} 
strategies, but by intentional cultivation and by the long time since their introduction. Eight species of North American origin and 7 woody species are among the top ten. The high rate of woody species among the most invasive plants corresponds with global trends: trees created the largest proportion $(32 \%)$ of a representative invasive alien plant sample of 135 PAs globally (FoxCROFT et al., 2017). According to De Poorter' list (2007), 67\% of the most important plant invaders in Europe are trees and shrubs, and this rate is probably similar in the European PAs (PYŠEK et al., 2013). The Jaccard index shows $26 \%$ similarity $\left(S_{J}=0.2608\right)$ between the most harmful plant species of European and Hungarian PAs. Similar to invasive animals, there are plants, which are native in Hungary (e.g. Acer pseudoplatanus L.) but alien in some part of Europe, therefore they are not in the Hungarian list. The spread of some species has climatic limitation (e.g. Rhododendron spp., Carpobrotus edulis (L.) N.E.Br.) in Hungary, while others e.g. Opuntia spp. and Buddleja davidii Franch. are only at the beginning of their invasion. In contrary, some in Hungary highly invasive species, e.g. Celtis occidentalis L., Elaeagnus angustifolia L., and Fraxinus pennsylvanica Marshall are missing from the list of European PAs. Comparing the top 25 invasive alien species occurring in the Hungarian and Czech PAs (PYšEK et al., 2002, 2012, 2013), only nine taxa are common in both lists. The explanations of differences could be the distinct climatic and geographical factors, and that Hungarian research focused especially on neophytes and excluded the archeophytes.

\section{Conclusions}

In addition to the habitat loss and fragmentation, both Hungarian and European PA managers considered invasive alien species to be the most important factor in biodiversity loss in protected areas. Eradication, control and prevention were mentioned among the best strategies against invasive species in both surveys, but Hungarian PA managers emphasized the efficiency of habitat restoration and regulatory as well. The checklists of invasive animals and plants of both European and Hungarian PAs were incomplete, but this lack is more significant in Hungary especially in the case of invasive animal species. Just as the presence of invasive animals, the problem they cause is less detected in Hungary, so control activities are rare in protected areas but more common in agriculture or forestry. The damage in agriculture and forestry caused by invasive alien species were regarded considerable by Hungarian PA managers while European respondents regarded it insignificant. These differences can be explained by the high proportion of intensively managed arable lands and pastures in Hungary. Comparing the most harmful animals and plants in Hungarian and European PAs, we found nearly $30 \%$ similarity. Considering the spatial, geographic and climatic differences between the two areas, this similarity is not insignificant. Behind the differences are the different indigenousness and habitat or climatic preferences of species. Among the species that are missing from the Hungarian list there are some, which have not been detected in Hungary yet, while others occur in Hungary but not belong to the most harmful ones. All of these species could be potentially invasive, therefore they should be monitored with special attention in Hungary, so their early detection can help the rapid response considerably. Species, which are highly invasive in Hungary, but are missing from the European PAs list, such as Celtis occidentalis, Elaeagnus angustifolia and Fraxinus pennsylvanica may pose a potential threat to other protected areas of Europe. These species and those that appear in both lists at a significant dominance we recommend considering for inclusion in the European Regulation list taking into account the precautionary principle. Both European and Hungarian lists have been strongly affected by agriculture, horticulture, and forestry, widely planted ornamental or forestry trees or propagated fish and wild game species compose the high proportion of the top invasive species. Because of this, the compilation of regulatory lists is not only scientific, but an economic and political issue as well. In our opinion, real improvement could be reached by the compilation of a variety of lists with different regulation and restriction systems. We feel it is necessary to make distinction between species targeted for full eradication and species targeted with only control in PAs, Natura 2000 areas, and their buffer zones.

\section{Acknowledgements}

We would like to express our thanks the experts of the Hungarian National Park Directorates for data collection, Andrea Monaco for submitting the results of the European survey, and László Lőkös for proofreading in English. The survey was supported by LIFE10NAT/HU/000020 LIFE+ and EFOP-3.6.1-16-2016-00018 grant "Improving the role of research+development+innovation in the higher education through institutional developments assisting intelligent specialization in Sopron and Szombathely" projects.

\section{References}

Balogh, L., Dancza, I., Király, G., 2008. Preliminary report on the grid-based mapping of invasive plants in Hungary. NeoBiota, 7: 105-114.

Bartha, D., Csiszár, Á., Zsigmond, V., 2008. Black locust (Robinia pseudoacacia L.). In Botta-Dukát, Z., BALOGH, L. (eds). The most important invasive plants in Hungary. Vácrátót: Hungarian Academy of Sciences, Institute of Ecology and Botany, p. 63-76.

Bódis, E., Borza, P., Potyó, I., Puky, M., Weipert, A., Guti, G., 2012. Invasive mollusc, crustacean, fish and reptile species along the Hungarian section of the River Danube and some connected waters. Acta Zoologica Academiae Scientiarum Hungaricae, 58: 29-45.

Borza, P., Czirok, A., Deák, C., Ficsór, M., Horvai, V., Horváth, Z., Juhász, P., Kovács, K., Szabó, T., Vad, C.F., 2011. Invasive mysids (Crustacea: Malacostraca: Mysida) in Hungary: distributions and dispersal mechanisms. North-Western Journal of Zoology, 7: 222-228. 
BоттA-Dukát, Z., 2008. Invasion of alien species to Hungarian (semi-) natural habitats. Acta Botanica Hungarica, 50: 219-227.

BotTA-Dukát, Z., BALOGH, L. (eds), 2008. The most important invasive plants in Hungary. Vácrátót: Hungarian Academy of Sciences, Institute of Ecology and Botany. $255 \mathrm{p}$.

BRUNDU, G., 2014. Invasive alien plants in protected areas in Mediterranean islands: knowledge gaps and main threats. In Foxcroft, L.C., PyšEK, P., Richardson, D.M. Genovesi, P. (eds). Plant invasions in protected areas: patterns, problems and challenges. Dordrecht: Springer, p. 395-422.

Carpio, A.J., Guerrero-Casado, J., Barasona, J.A., TortoSA, F.S., Vicente, J., Hillström, L., Delibes-Mateoset, M., 2016. Hunting as a source of alien species: a European review. Biological Invasions, 19 (4): 1197-1211.

Commission Implementing Regulation (EU) 2016/1141 of 13 July 2016 adopting a list of invasive alien species of Union concern pursuant to Regulation (EU) No 1143/2014 of the European Parliament and of the Council. Official Journal of the European Union, L 189: 4-8.

Commission Implementing Regulation (EU) 2017/1263 of 12 July 2017 updating the list of invasive alien species of Union concern established by Implementing Regulation (EU) 2016/1141 pursuant to Regulation (EU) No 1143/2014 of the European Parliament and of the Council Official Journal of the European Union, L 182: 37-39.

Commission Implementing Regulation (EU) 2019/1262 of 25 July 2019 amending Implementing Regulation (EU) 2016/1141 to update the list of invasive alien species of Union concern. Official Journal of the European Union, L 199: 1-4.

Csecserits, A., Botta-Dukát, Z., Kröel-Dulay, Gy., LhotSKy, B., ÓNOdI, G., RÉDeI, T., Halassy, M., 2016. Tree plantations are hot-spots of plant invasion in a landscape with heterogeneous land-use. Agriculture, Ecosystems and Environment, 226: 88-89.

Csiszár, Á., KordA, M. (eds), 2017. Practical experiences in invasive alien plant control. Rosalia Handbooks 3. Budapest: Duna-Ipoly National Park Directorate. 249 p.

CsóKA, Gy., CsóKÁNÉ Hirka, A., Szőcs, L., 2012. Rovarglobalizáció a magyar erdőkben [Insect globalization in the Hungarian forests]. Erdészettudományi Közlemények, 2 (1): $187-198$

De Poorter, M., 2007. Invasive alien species and protected areas: a scoping report. Part 1. Scoping the scale and nature of invasive alien species threats to protected areas, impediments to invasive alien species management and means to address those impediments. Global Invasive Species Programme, Invasive Species Specialist Group. $94 \mathrm{p}$.

EPPO, 2020. EPPO Global database. EPPO Lists of invasive alien plants. [online]. [cit. 2020-04-29]. https://www. eppo.int/ACTIVITIES/invasive_alien_plants/iap_lists

European Commission - Joint Research Centre - European Alien Species Information Network (EASIN). Species search and mapping, Advanced search. [online]. [cit. 2020-04-29]. http://alien.jrc.ec.europa.eu/SpeciesMapper
EUROPEAN COMMISSION. List of invasive alien species of Union concern. [online]. [cit. 2020-04-29]. https://ec.europa.eu/ environment/nature/invasivealien/list/index_en.htm

Foxcroft, L.C., Pyšek, P., Richardson, D.M., Genovesi, P., MacFadyen, S., 2017. Plant invasion science in protected areas: progress and priorities. Biological Invasions, 19: $1353-1378$.

Foxcroft, L.C., Pyšek, P., Richardson, D.M., Pergl, J., Hulme, P.E., 2014. The bottom line: impacts of alien plant invasions in protected areas. In FoxCROFT, L.C., PYŠEK, P., Richardson, D.M., Genovesi, P. (eds). Plant invasions in protected areas: patterns, problems and challenges. Dordrecht: Springer, p. 19-41.

Gallardo, B., Aldridge, D.C., González-Moreno P., Pergl, J., Pizarro, M., Pyšek, P., Thuiller, W., Yesson, C., VILÀ, M., 2017. Protected areas offer refuge from invasive species spreading under climate change. Global Change Biology, 23 (12): 1-13.

Genovesi, P., Monaco, A., 2014. European guidelines on protected areas and invasive alien species. Strasbourg/ Rome: Council of Europe, Regional Parks Agency, Lazio Region. 58 p.

Hulme, P.E., Pyšek, P., Pergl, J., Jarošík, V., Schaffner, U., VILÀ, M., 2013. Greater focus needed on plant invasion impacts in protected areas. Conservation Letters, 7 (5): 459-466.

Kazinczi, G., BÉres, I., NovÁK, R., BíRó, K., PAThy, Z., 2008. Common ragweed (Ambrosia artemisiifolia): a review with special regards to the results in Hungary. I. Taxonomy, origin and distribution, morphology, life cycle and reproduction strategy. Herbologia, 9 (1): 55-91.

Keller, R. P., GeIST, J., JeschKe, J. M., KühN, I., 2011. Invasive species in Europe: ecology, status, and policy. Environmental Sciences Europe, 23: 1-17.

Király, G., SteTÁK, D., BÁNyász, D., 2008. Spread of invasive macrophytes in Hungary. NeoBiota, 7: 123-130.

Kleinbauer, I., Dullinger, S., Peterseil, J., Essl, F., 2010. Climate change might drive the invasive tree Robinia pseudacacia into nature reserves and endangered habitats. Biological Conservation, 143: 382-390.

Magyar Állami Természetvédelem, 2020. Természetes állat- és növényvilágra veszélyt jelentő idegenhonos inváziós fajok hazai tudományos alapú jegyzékei. [online]. [Science-based lists of non-native invasive species posing a threat to native fauna and flora]. [cit. 2020-04-29]. http://www.termeszetvedelem.hu/termeszetes-allat-esnovenyvilagra-veszelyt-jelento-idegenhonos-invaziosfajok-hazai-tudomanyos-alapu-jegyzekei

Medina, F.M., Bonnaud, E., Vidal, E., Nogales, M., 2013. Underlying impacts of invasive cats on islands: not only a question of predation. Biodiversity Conservation, 23: 327-342.

Nentwig, W., Bacher, S., Kumschick, S., Pyšek, P., Vilà, M., 2018. More than "100 worst" alien species in Europe. Biological Invasions, 20: 1611-1621.

O’Brien, J., Devillard, S., Say, L., Vanthomme, H., LÉGer, F., Ruette, S., Pontier, D., 2009. Preserving genetic integrity in a hybridising world: are European Wildcats (Felis silvestris silvestris) in eastern France distinct from sympatric feral domestic cats? Biodiversity Conservation, 18: $2351-2360$ 
PyŠEK, P., DANihelKa, J., SÁdlo, J., ChrTeK, J. JR., ChytrÝ, M., Jarošík, V., Kaplan, Z., KrahuleC, F., Moravcová, L., Pergl, J., Štajerová, K., TichÝ, L., 2012. Catalogue of alien plants of the Czech Republic (2nd edition): checklist update, taxonomic diversity and invasion patterns. Preslia, 84: 155-255.

Pyšek, P., Genovesi, P., Pergl, J., Monaco, A., Wild, J., 2013. Invasion of protected areas in Europe: an old continent facing new problems. In FoxCROFt, L.C., PYŠEK, P., Richardson, D.M., Genovesi, P. (eds). Plant invasions in protected areas: patterns, problems and challenges. Dordrecht: Springer, p. 209-240.

PYŠEK, P., JAROŠÍK, V., KUČERA, T., 2002. Patterns of invasion in temperate nature reserves. Biological Conservation, 104: 13-24.

Pyšek, P., Richardson, D.M., Pergl, J., Jarošík, V., SixTOVÁ, Z., WeBER, E., 2008. Geographical and taxonomic biases in invasion ecology. Trends in Ecology \& Evolution, 23: 237-244.

RIPKA, G., 2010. Jövevény kártevő ízeltlábúak áttekintése Magyarországon [An overview of the alien arthropod pest species in Hungary]. Növényvédelem, 46 (2): 45-58.

Roy, D., Alderman, D., Anastasiu, P., Arianoutsou, M., Augustin, S., Bacher, S., Başnou, C., Beisel. J., Bertolino, S., Bonesi. L., Bretagnolle, F., Chapuis, J.L., Chauvel, B., Chiron, F., Clergeau, P., Cooper, J., Cunha, T., Delipetrou, P., Desprez-Loustau, M., Détaint, M., Devin, S., Didžiulis, V., Essl, F., Galil, B.S, Genovesi, P., Gherardi, F., Gollasch, S., Hejda, M., Hulme, P.E, Josefsson, M, Kark, S., Kauhala, K., Kenis, M, Klotz, S., Kobelt, M., Kühn, I., LambDON, P.W, Larsson, T., Lopez-VAamonde, C., Lorvelec, O., Marchante, H., Minchin, D., Nentwig, W., Occhipinti-Ambrogi, A., Olenin, S., Olenina, I., Ovcharenko, I., Panov, V.E, Pascal, M., Pergl. J., Per-
Glová, I., Pino, J., Pyšek, P., Rabitsch, W., Rasplus, J., Rathod, B., Roques, A., Roy, H., Sauvard, D., Scalera, R., Shiganova, T.A, Shirley, S., Shwartz, A., Solarz, W., VilÀ, M, Winter, M., Yésou, P., Zaiko, A., AdriAens, T., Desmet, P., Reyserhove, L., 2019. DAISIE - Inventory of alien invasive species in Europe. Version 1.6. Research Institute for Nature and Forest (INBO). Checklist dataset. [online]. [cit. 2020-04-29]. https://www.gbif. org/dataset/39f36f10-559b-427f-8c86-2d28afff68ca

Roy, H.E., Adriaens, T., IsaAC, N.J.B., Kenis, M., Onkelinx, T., San Martin, G., Brown, P.M.J., Hautie, L., Poland, R., Roy, D.B., Comont, R., Eschen, R., Frost, R., ZINdel, R., Van Vlaenderen, J., Nedvěd, O., Ravn, H.P., GrÉgoire J-C., De Biseau, J-C., Maes, D., 2012. Invasive alien predator causes rapid declines of native European ladybirds. Diversity and Distributions, 18: 717-725.

Takács, P., Czeglédi, I., Ferincz, Á., SÁly, P., Speciár, A., VitáL, Z., WeIPerth, A., Erős, T., 2017. Non-native fish species in Hungarian waters: historical overview, potential sources and recent trends in their distribution. Hydrobiologia, 795 (1): 1-22.

TöröK, K., BotTA-Dukát, Z., DANCZA, I., NÉmeth, I., Kiss, J., MiháLY, B., MAGYAR, D., 2003. Invasion gateways and corridors in the Carpathian Basin: biological invasions in Hungary. Biological Invasions, 5: 349-356.

UsHER., M.B. 1988. Biological invasions of nature reserves: a search for generalizations. Biological Conservation, 44: $119-135$.

VeenVliet, J.K., Humar, M., 2011. Tujerodne vrste na zavarovanih območjih [Alien species in protected areas]. Report on capacity building activity in the framework of the WWF project Dinaric Arc Ecoregion. Ministry of Environment, Slovenia. $73 \mathrm{p}$.

Received June 19, 2020

Accepted September 9, 2020 
Appendix. Questionnaire about invasive alien species and protected areas in Europe.

1. General information

First name:

Family name:

Email address:

Country:

Name of protected area:
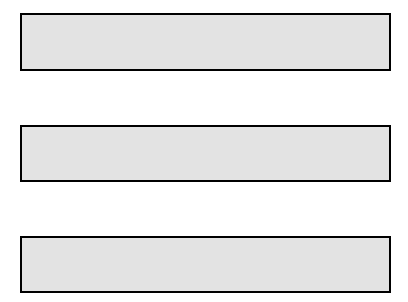

WDPA ID:

The WDPA ID is the unique identification number assigned by UNEPWCMC to each marine or terrestrial protected area.

You can find the WDPA ID of your protected area at http://www.wdpa.org/

2. What in your opinion are the most important threats to your protected area? (Rank 1 is the most important; please tick at least 3 responses).

$\begin{array}{lccccc} & \text { rank 1 } & \text { rank 2 } & \text { rank 3 } & \text { rank 4 } & \text { rank 5 } \\ \text { Pollution } & \square & \square & \square & \square & \square \\ \text { Overgrazing } & \square & \square & \square & \square & \square \\ \text { Erosion } & \square & \square & \square & \square & \square \\ \text { Overexploitation } & \square & \square & \square & \square & \square \\ \text { Habitat loss/fragmentation } & \square & \square & \square & \square & \square \\ \text { Poaching } & \square & \square & \square & \square & \square \\ \text { Tourism } & \square & \square & \square & \square & \square \\ \text { Invasive species } & \square & \square & \square & \square & \square \\ \text { Waste } & \square & \square & \square & \square & \square \\ \text { Other } & \square & \square & \square & \square & \square\end{array}$

Specify other

3. Is there a checklist of alien animals present in your protected area?

$\square$ Yes

$\square$ No

Partial (please specify what kind of list).

It is very important to specify if you have only partial checklists (e.g. only invasive animals, only some taxonomic groups, etc.). 
4. Top invasive species (most harmful) in your protected area: ANIMALS. (Please indicate at least 1 species).

Species 1

Species 2

Species 3

Species 4

Species 5


5. What are the kind of management activities of the top invasive ANIMALS being implemented in your protected area? (Please tick at least 1 response).

\begin{tabular}{|c|c|c|c|c|c|c|c|c|}
\hline $\begin{array}{c}\text { Monitoring } \\
\qquad \& \\
\text { surveillance }\end{array}$ & Prevention & Control & Eradication & $\begin{array}{c}\text { Habitat } \\
\text { restoration }\end{array}$ & $\begin{array}{l}\text { Native } \\
\text { species } \\
\text { recovery }\end{array}$ & Communication & Education & $\begin{array}{c}\text { Public } \\
\text { involvement }\end{array}$ \\
\hline
\end{tabular}

\begin{tabular}{|c|c|c|c|c|c|c|c|c|c|c|}
\hline Species 1 & $\square$ & $\square$ & $\square$ & $\square$ & $\square$ & $\square$ & $\square$ & $\square$ & $\square$ & $\square$ \\
\hline Species 2 & $\square$ & $\square$ & $\square$ & $\square$ & $\square$ & $\square$ & $\square$ & $\square$ & $\square$ & $\square$ \\
\hline Species 3 & $\square$ & $\square$ & $\square$ & $\square$ & $\square$ & $\square$ & $\square$ & $\square$ & $\square$ & $\square$ \\
\hline Species 4 & $\square$ & $\square$ & $\square$ & $\square$ & $\square$ & $\square$ & $\square$ & $\square$ & $\square$ & $\square$ \\
\hline Species 5 & $\square$ & $\square$ & $\square$ & $\square$ & $\square$ & $\square$ & $\square$ & $\square$ & $\square$ & $\square$ \\
\hline
\end{tabular}

6. Is there a checklist of alien plants present in your protected area?

$\square$ Yes

$\square$ No

Partial (please specify what kind of list)

It is very important to specify if you have only partial checklists (e.g. only invasive plants, only some taxonomic groups, etc.).

7. Top invasive species (most harmful) in your protected area: PLANTS. (Please indicate at least 1 species). Species 1

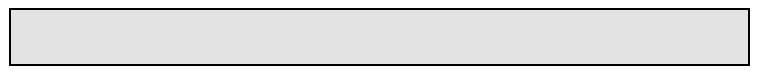

Species 2

Species 3

Species 4



Species 5 
8. What are the kind of management activities of the top invasive PLANTS being implemented in your protected area? (Please tick at least 1 response).

$\begin{array}{ccccccccc}\begin{array}{c}\text { Monitoring } \\ \&\end{array} & \text { Prevention } & \text { Control } & \text { Eradication } & \begin{array}{c}\text { Habitat } \\ \text { restoration }\end{array} & \begin{array}{c}\text { Native } \\ \text { species } \\ \text { recovery }\end{array} & \begin{array}{c}\text { Communication } \\ \text { Education }\end{array} & \begin{array}{c}\text { Public } \\ \text { involvement }\end{array} \\ \square & \square & \square & \square & \square & \square & \square & \square & \square \\ \square & \square & \square & \square & \square & \square & \square & \square & \square \\ \square & \square & \square & \square & \square & \square & \square & \square & \square \\ \square & \square & \square & \square & \square & \square & \square & \square \\ \square & \square & \square & \square & \square & \square & \square & \square\end{array}$

9. What in your opinion are the worst impacts caused by invasive species in your protected area? (Rank 1 is the worst; please tick at least 1 response).

rank $1 \quad \operatorname{rank} 2 \operatorname{rank} 3 \quad \operatorname{rank} 4 \quad \operatorname{rank} 5$

\begin{tabular}{|c|c|c|c|c|c|}
\hline Competing with native species & $\square$ & $\square$ & $\square$ & $\square$ & $\square$ \\
\hline Predating native species & $\square$ & $\square$ & $\square$ & $\square$ & $\square$ \\
\hline Transmitting diseases to native species & $\square$ & $\square$ & $\square$ & $\square$ & $\square$ \\
\hline Hybridising with native species & $\square$ & $\square$ & $\square$ & $\square$ & $\square$ \\
\hline Affecting habitats & $\square$ & $\square$ & $\square$ & $\square$ & $\square$ \\
\hline Ecosystem changes (trophic level, fire regime, hydrology, etc.) & $\square$ & $\square$ & $\square$ & $\square$ & $\square$ \\
\hline Affecting human health (vector of diseases, allergenic, toxic, etc.) & $\square$ & $\square$ & $\square$ & $\square$ & $\square$ \\
\hline Damaging infrastructures & $\square$ & $\square$ & $\square$ & $\square$ & $\square$ \\
\hline Damaging landscape & $\square$ & $\square$ & $\square$ & $\square$ & $\square$ \\
\hline Damaging agriculture/forestry/aquaculture & $\square$ & $\square$ & $\square$ & $\square$ & $\square$ \\
\hline Other & $\square$ & $\square$ & $\square$ & $\square$ & $\square$ \\
\hline
\end{tabular}

Specify other

10. What in your opinion are the most effective management options to deal with the spread of invasive species in your protected area? (Rank 1 is the most effective; please tick at least 1 response).

rank $1 \quad \operatorname{rank} 2 \operatorname{rank} 3 \quad \operatorname{rank} 4 \quad \operatorname{rank} 5$

$\begin{array}{llllll}\text { Prevention } & \square & \square & \square & \square & \square \\ \text { Control } & \square & \square & \square & \square & \square \\ \text { Eradication } & \square & \square & \square & \square & \square \\ \text { Habitat restoration } & \square & \square & \square & \square & \square \\ \text { Native species recovery } & \square & \square & \square & \square & \square \\ \text { Communication } & \square & \square & \square & \square & \square \\ \text { Education } & \square & \square & \square & \square & \square \\ \text { Regulatory } & \square & \square & \square & \square & \square \\ \text { Public involvement } & \square & \square & \square & \square & \square \\ \text { Other } & \square & \square & \square & \square & \square\end{array}$

Specify other 
11. What in your opinion are the key impediments in dealing with the spread of invasive species in your protected area? (Rank 1 is the most important; please tick at least 1 response).

$$
\text { rank } 1 \quad \operatorname{rank} 2 \operatorname{rank} 3 \operatorname{rank} 4 \operatorname{rank} 5
$$

$\begin{array}{llllll}\text { Limited resources (financial/staff) } & \square & \square & \square & \square & \square \\ \text { Lack of capacity } & \square & \square & \square & \square & \square \\ \text { Lack of awareness } & \square & \square & \square & \square & \square \\ \text { Lack of information } & \square & \square & \square & \square & \square \\ \text { Public/stakeholders opposition to management } & \square & \square & \square & \square & \square \\ \text { Legal impediments } & \square & \square & \square & \square & \square \\ \text { Institutional impediments } & \square & \square & \square & \square & \square \\ \text { Other } & \square & \square & \square & \square & \square\end{array}$

Specify other

12. Do you have any comments about the survey?

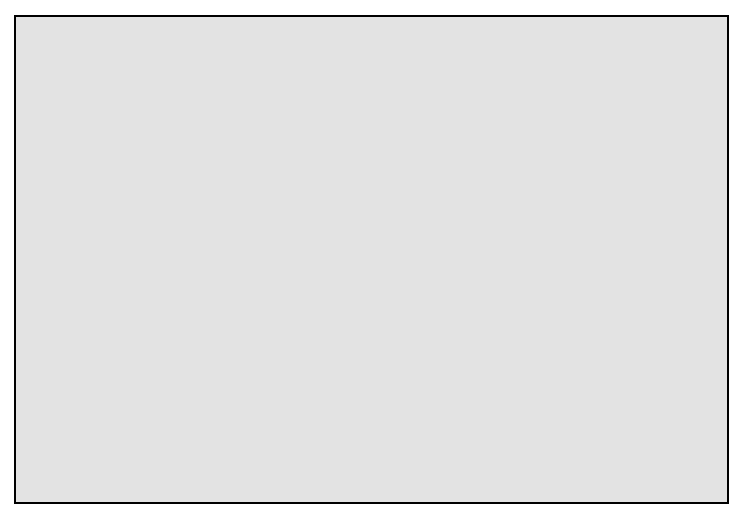

Thank you very much for participating in the survey! 